\title{
AZ ÉRDEKLŐDÉS HULLÁMAI \\ A KöNYVTÁROS ÚJ SZEREPLEHETŐSÉGE A KÖZREADÁS ÉS A PÉLDAMUTATÁS KÖZÖTT
}

\author{
Fodor János \\ ELTE BTK Könyvtár- és Információtudományi Intézet \\ fodor.janos.konyvttud@btk.elte.hu
}

DOI: $10.31915 / N W S .2018 .6$

Waves of interest - Librarian's role between availability and exemplification For libraries, being present at the social media offer important ways (maybe the most important or just as supplement, dependig on different library types) to enhance the discoverability and accessibility of their collections. Surveys show clear, that the virtual proof of existence isnt enough. Effective institutional social media prescence demands teamworking and careful preparation in order to be successful. It's obvious, thet the real success and marketing goal for collections would be the growing number of spontaneous sharing, remixing, commenting of digitized objects from our digital collection. But where is the border in our responsibility between making collections available online and exemplify the use of created systems, databases, digital libraries?

Based on a case study of our current webproject, we wish to present possibile strategies of plannable exemplification. Assuming the librarians of our age became interested in social media, it is easily possibile to well-prepare a collections with teasers, supplemental background informations to channel the passion and real interest of wide range of social media users.

The works of content-development workshop at ELTE LIS became integrated part of the university training of library professionals with more than 15 years of experience in building and evaluate online representations of special collections, part colletions, tematic photo series with historic value. Our projects serves the education as working models with the focus being on the user and access, promotion of the existence of the library collection and the library itself.

The peresentation referencing our new project: Hullámfürdő záróra elött - developed with the Szabó Ervin Library of Budapest and the Centre for Digital Humanities of ELTE.

Keywords: library and information science, librarian training, content development, collections management, digital literacy, social media presentation, local history

\section{Bevezetés}

Egy-egy új, digitalizált gyüjtemény örömmel tölti el a róla értesülö, a téma iránt érdeklödő olvasót, szakembert. Ám az új projektek a szaporodó digitális kincstárak sűrű mezőnybe érkeznek, s a fő kérdés nem is a hosszú távú fenntartásuk.

A 2010-es évekre a digitalizálás, a nemzeti örökség archiválásának fontossága hétköznapi irányelvvé vált. Hosszú évek munkájával, de közismertté váltak hazai és nemzetközi digitális könyvtári szolgáltatások, s az elektronikus könyvtári keresők, katalógusok és dokumentumtárak mellett terjedni kezdtek a nyilvános intézményi (pl. egyetemi) repozitóriumok, dolgozattárak, Open Access publikálási formák is. 


\section{NETWORKSHOP 2018}

Ha a digitális állományokat szolgáltató gyüjteményekben, adatbázisokban a könyvtári állomány virtuális otthonra lel, egyúttal el is szakad a gondozására, ajánlására hivatott szakemberektől, a könyvtárosoktól. A virtuális gyűjtemények gyarapítása és folyamatos fejlesztése mellett megmaradhat-e vagy pótolható-e az a könyvtári és munkatársi környezet, amely magáénak érezve az állományt, napról napra elösegítette annak mélyebb feltárását, megismerését, s értékeinek az olvasók figyelmébe ajánlását?

Hiába áll majdan rendelkezésre az írott emberi tudás átfogó digitális tára, ha az archívumok meglétéröl csak passzív ismerettel bír az olvasó. Ha az aktív használatra nem szakít időt, létük inkább megnyugvással tölti el, a feldolgozottság és elérhetöség tudata felületes biztonságérzetet ad s csökkenti a mélyebb megismerésük iránt felfedező kedvét.

A figyelem, az idő lekötése és a kíváncsiság felkeltése a könyvtárak számára napjainkban ugyanolyan kulcskérdéssé válik, mint a pedagógusok számára a kötelező olvasmányok célszerü frissítése, vagy a múzeumok számára az izgalmas, interaktív események, tárlatok tervezése.

Kutatásaink bizonyították1, hogy a könyvtárak közösségi média jelenlétében dominál az ajánlás, figyelemfelkeltés vágya, de a stratégia sok esetben átgondolatlan: a könyvtár nevében gyakorlatilag személyes érdeklődése szerint oszt meg számára érdekes tartalmakat egy-egy munkatárs. A tudatos stratégiát gátolhatja, hogy nincs saját, megosztásra kész digitalizált gyűjtemény, vagy hogy gyűjteményük olyan adatbázisba került, amely jelen van - a könyvtártól független identitásként - a közösségi médiában, a két identitás fenntartói között azonban nincsen szerves, megtervezett szakmai kapcsolat.

A közösségi médiajelenlét vizsgálata során egyértelművé vált, hogy a nagy digitális gyüjtemények aktivitása elenyésző a közösségi médiatartalomban. Néhány, már korábban is aktív szereplőtől eltekintve az újabban létesült vagy nagyobb könyvtáraink gondozásában működő, elkülöníthető gyűjteményekről jóformán tudomást sem szerezhet az, aki a közösségi médiából tájékozódik érdekes tartalmakról.

Így továbbra is csak a közösségi weben beágyazottabb, vagy tágabb médiamegjelenéssel támogatott gyűjtemények (pl. fotótörténet területén a Fortepan és a Mai Manó Ház) aratja le, monopolizálja - a sikerükkel bizonyíthatóan meglévő - közösségi érdeklődést a digitalizált kulturális kincsek iránt.

\section{Könyvtártudományi oktatási vetület}

Az ELTE egyetemi könyvtárosképzésében olyan kísérleti projektek során fejlesztjük hallgatóink digitális, informatikai kompetenciáit, amelyek reflektálnak a hálózati közegben visszavonhatatlanul megváltozott 
olvasási, tájékozódási szokásokra². Együttmüködő partnereink segítségével élő, izgalmas tartalmakat fejlesztünk, imitálva, modellezve egy-egy digitális részgyüjtemény adekvát publikálását, eleven közzétételét. A sokszínű, érdeklődés hullámaira rájátszó tájékoztató kompetenciák fejlesztésében az intézetünk támogatásával létesülő Digitális Bölcsészet Központ müködésétől is további fejlődést remélünk. Projektjeink tanulságai alapján a könyvtárosság és a könyvtártudomány hálózati tájékoztató aktivitásánakúj területe vagy a meglévő tájékoztató szakterület új vetülete rajzolódhat ki. A digitalizálással nem ér, nem érhet véget a könyvtár felelössége a rá bízott tartalmak közvetítésében. Szükséges a kreatív, közvetítő magatartás és az ezt lehetővé tévő kompetenciák fejlesztése.

A tartalomszolgáltatási mühelyünkben készülő kísérleti projektek elsősorban képgyüjtemények, helyés kortörténeti értékü dokumentum-együttesek közreadására épülnek. Ahogy a közösségi médiában, úgy a hallgatók körében is ilyen, általános érdeklődésre számot tartó gyűjtemények közreadásával modellezhető leginkább a motiváltan végzett tevékenység, amely egy munkahelyen, a saját gyüjtemény közreadása érdekében kollégák és vezetők számára egyaránt fontos. A közös munka eredményességéhez elengedhetetlen a tudat, hogy minden résztvevő szerepe nélkülözhetetlen, és munkájuk minősége a teljes tartalomszolgáltatás értékét emeli. A hallgatók vagy önkéntes diákok bevonása digitalizálási, gyüjteményfejlesztési munkákba világszerte hasonló problémákkal és előnyökkel jár: bár hatékonyan fejleszti a szakmai kompetenciákat és a digitális írástudást, de a szakképzett, már betanított munkaerőhöz képest számolni kell a helyzet limitációival is³.

Míg egy könyvtárban, kutatóhelyen általában biztosítottak a keretek és az idő a folyamatos felzárkózásra, a munkafolyamatban otthonosabb kolléga szerepkörének fokozatos átvételére, addig a felsőoktatási mühelymunka során csak fél év áll rendelkezésre egy-egy tanegység elvégzésére. Több félév alatt, folyamatos kutatással bár biztonságosabban létrehozhatóak komoly eredmények, ám számolni kell azzal is, hogy a hallgatók cserélödnek, s a minőség fenntartása mellett biztosítani kell azt is, hogy munkájuk hasznosulásáról még értesüljenek. Egy félév alatt a tizenkét, általában másfél órás alkalom nem sok a 10-20 új munkatárs felkészítésére, egy-egy közös projekt megértésére, a feladatok kiosztására, a minőségi munkához szükséges instrukciókra és - lehetőség szerint - az elkészült feladatok lezárására, értékelésére, az eredmény közzétételére. Ilyen szempontból nézve, tartalomfejlesztési projektjeink mindegyike rövid határidővel vállalt projektmunka-helyzetet szimulál. Komoly oktatói felelösség, hogy a gyakorlat is sikerélménnyel záruljon, s az értelmesnek ígért feladatokból is összeálljon a motiváló célként megjelölt eredmény.

2 Fodor János, and Kiszl Péter. „,Developing Digital Collections: a Training Model of Digital Humanities Web Projects in Library and Information Science Education." Informatio et Scientia. Information Science Research 1 (1) (2018): 1-27. https://wow.umcs.pl/czasopisma/controller/Default/module/Ejournals/action/downloadContent/cid/81

3 Skulan, Naomi. „Staffing with students: Digitizing campus newspapers with student volunteers at the University of Minnesota, Morris." Digital Library Perspectives, 34. évf. 1. sz. (2018): 32-44. https://doi.org/10.1108/dlp-07-2017-0024 


\section{NETWORKSHOP 2018}

Eddigi tapasztalatainkból leszürt legfontosabb irányelveink:

- Olyan feladatok vállalhatók el egyetemi mühelymunka keretében, amelyek a kijelöléstöl a befejezésig lehetőleg változatlan munkatársi közegben megvalósíthatóak, befejezhetőek vagy publikálható részeredményekhez vezetnek.

- A projektek kidolgozásához és közreadásához célszerü olyan formátumot is választani, hogy a közös munka egyetlen féléve önálló - vagy egy nagyobb mü-egészen belül is elkülöníthető eredményt alkosson.

- A projektet olyan, azonos nehézségü részfeladatokra kell bontani, amelyeket képesek a közremüködők külön-külön - az elvárt munkával és megkövetelt figyelemmel - megfelelö szinten elvégezni.

- Figyelembe kell venni aktuális ismereteiket, előre kell tervezni a félév során szükségessé váló új ismeretek oktatását, a reálisan megtanulható, megszerezhető kompetenciát és a kialakuló rutint.

- A csapatmunka során - azaz az órákon - elsősorban a gyengébben teljesítők lemaradását kell orvosolni.Amásokszámáraistanulságosproblémákatmegkellosztaniaprojektbelsőnyilvánossága előtt. A szűkös konzultációs időt a problémák megoldására kell fordítani, a kiválóbban teljesítő munkatársak kérdéseire és ötleteire e-mailben vagy megosztott kommunikációs felületen is hatékonyan lehet reagálni.

- Míg az elvárt kompetenciákat fejleszteni kötelességünk, biztosítanunk kell a kiemelkedő készségü hallgatók kibontakozását, lehetőség szerint a közös munka eredményeit bővítő, gazdagító módon. A projekt rövid határideje ellenére sem kezelhetjük tehát homogén munkaerőkként, felcserélhető szereplőkként hallgatóinkat.

Szólnunk kell végezetül a résztvevőket a projektekhez füző érzelmi kapcsolatról is. A könyvtárak, tájékoztató intézmények, múzeumok vagy memória-intézmények projektjei saját profiljukhoz kapcsolódnak. Elhivatott munkatársaik számára fontos témák ezek, de az egyetemi hallgatók érdeklődése sokféle lehet, s különösen igaz ez egy, a könyvtártudományhoz hasonlóan interdiszciplináris tudományágnak szentelt szakon belül. A továbbiakban ismertetett projektek kapcsán általánosságban is elmondható: a résztvevők számára fontosak a saját valóságukhoz, élményeikhez köthető témák, a szakmai fejlödésükhöz kapcsolható tanulságok, a közérdeklődésre számot tartó értékteremtés. E motiváló tényezők állandó jelenlétére érdemes gondot fordítanunk az elvállalt munkák, elindított projektek kiválasztásakor is.

\section{Hullámfürdő záróra előtt}

A 2016-ban bemutatott Könyvek Holokausztja virtuális kiállítás után másodízben fogtunk közös projektbe a FSZEK Budapest Gyüjteményével. Sándor Tibor osztályvezető különleges fotóhagyaték közzétételével bízta meg intézetünket: a képeket készítő Pusztai Sándor a Gellért fürdő úszómestere volt a 
II.világháború előttiévtizedben. Fotóin megörökítettea Budapestbüszkeségének számító, világszínvonalú Hullámfürdőt élvező vendégeket. A több mint 600 fotó kivételesen bőséges képanyag ilyen rövid időszakból, azonos közegből, ráadásul az időszak elitjéről, s - tegyük hozzá - fürdőruhában, spontán helyzetekben, a paparazzi fotók korszaka előtt. A projekt a hallgatók több csoportjának és évfolyamának bevonásával már a 2016/2017-es tanévben elkezdődött. Feladatunk nem csak a képgyüjtemény közreadása volt, s nem is elsősorban a még ismeretlen fürdővendégek felismerése. Vállalt célunk az érdeklődés hullámainak felkeltése, a közösségi felismerés motiválása volt, merítve nemcsak saját, de nemzetközi tapasztalatokból is a gyüjteményi közösségi média kampányok tanulságaira vonatkozóan.

- Meghívtuk az egyetemi órákra az örököst, Pusztai Enikőt és a gyüjteményt fotótörténész szemmel felfedező Kincses Károlyt.

- A hallgatókkal több háttérkutatást végeztünk, s emeltünk a szolgáltatott tartalmi kontextusba: a történelmi, várostörténeti, müvelödéstörténeti korszakról, a korabeli fürdőéletről vagy a fürdőruhadivat változásáról készítettünk összeállításokat, lefedve a látogatók lehetséges érdeklődési területeit, asszociációit.

- A gyüjtemény böngészéséhez inspiráló összeállításokat, közösségi médiában megosztható ízelítőket készítettünk, kollázsokat állítottunk össze különböző, a képeket összefüző motívumok kiemelésével, hogy szimuláljuk a képeket böngésző, érdekességekre rácsodálkozó látogató természetes attitüdjét.

- A korszak kutatóit bevonva, több szakkönyvtárba ellátogatva bővítettük a felismert vagy felismerni vélt fürdővendégek körét, a tételek kommentálására alkalmas blogot, többféle megtekintő, áttekintő felületet készítettünk.

\section{Digitális bölcsészeti tanulság - a közvetítés kreatív feladata}

A Hullámfürdő záróra elött projekt során minduntalan szembesültünk az arcfelismerés nehézségeivel. Bárközvetlencélunkafotógyüjteményinspirálóközzétételevolt, nemkerülhettükmegazismertszemélyek keresését, kutatását, hiszen ha szeretnénk, hogy nagyszülökre, dédszülőkre bukkanjanak látogatóink, s velünk kutatva átfésüljék e közös múltunkból vett élettel teli mintát, célszerű megmutatnunk, mennyi kapcsolat füzi máris a korszak számon tartott történelméhez, kulturális életéhez.

Milyen jó lett volna csak „,ráereszteni” egy algoritmust a félezer képre, hogy kilistázza az ismert, ismerhető személyeket! Sőt, lépjünk tovább, az az algoritmus átfésülhetne digitalizált életrajzokat, lexikonokat, a Wikipédiát, s kigyüjthetné a kapcsolódó szócikkeket. Fölrajzolhatná a Pusztai Sándor képein szereplők kapcsolati hálóját egymással és további (a képeken nem szereplő, ám a történetírásban, kultúrtörténetben fontos, számon tartott) személyekkel. Ábrázolhatná sorsok alakulását térben - térképen - és időben: mikor, hol keresztezte egymásét útjuk, életpályájuk. Kapcsolódhatnának korabeli és mai fotók 


\section{NETWORKSHOP 2018}

lakhelyükről, életükhelyszíneiröl, munkahelyeikröl.Teremtettmüveikábrázolásai, könyvborítók, plakátok, müsorfüzet-lapok. Összekapcsolhatná az algoritmus munkásságukat történelmi eseményekkel, nevük előfordulásaival cikkekben, digitalizált könyvekben és sajtótermékekben. Kigyüjthetné emlékezetüket: bemutathatná, melyikükre mikor figyelt az utókor, a korszakról vagy hivatásterületükről szóló írások, filmek, rádió- és tévémüsorok mely időszakban születtek? Csökkent-e az érdeklődés irántuk idővel, vagy éppen növekedett? Beállíthatnánk szürőket, súlyozási skálákat, részletességi fokozatokat, hogy áttekinthetővé tegyük e kigyűjtött összefüggésrendszert, hogy olvasható, értelmezhető információegyütteseket kapjunk. Generáltathatnánk különböző nézeteket, akár a képeken szereplö személyek felöl tekintve a gyüjteményre, akár a kontextus felöl, pl. háttértanulmányként prezentálva, melynek szövegéből a fürdőző személyekre továbbutaló linkek nyitnák a mélyebb rétegeket.

Mindez - elméletben - már lehetséges. Bár a múlt nyomait feltáró adatbázisok, a különböző mühelyekben más és más formátumban közreadott digitalizált kép- és szöveggyüjtemények összekapcsolása, a bennük közzétett információk kinyerése ma még nehézkes és gyakran akadályokba ütközik, a napjainkban épített adatbázisok, vagy „élőben” rögzített adatok már kompatibilis formátumokban kerülnek rögzítésre. A rendszer, a lekérdezések, a „szüretelés” megkezdése, és a „kimenet”, a témához szabott új felület megtervezése egyszeri, nagy munka. A hozzáférés mélysége, a jogosultságok kezelése ugyanakkor - ha így készülnek majd a jövő kiállításai - komoly problémákat vet fel.

Látjuk, hogy a közösségi hálók illetéktelen „leszüretelésével” az üzemeltetőn kívül mások is ijesztő tudást szerezhetnek életünkről, s össze is kapcsolhatják azt máshol, más célból hagyott digitális lábnyomainkkal, aktivitásunkkal - netán telefonunk GPS-jeladóját és kameráját használva: pillanatnyi tartózkodási helyünkkel.

Bármilyen messzire vezet, mégis tanulságos mindez: a Nagy Testvéri disztópiához ugyanaz a technológiai integráltság közelít bennünket, amely rövidesen lehetővé teszi testre szabott, informatív, bármikor különböző igényeknek megfelelöen átrendezhető, tudományos hitelü dokumentumok vagy virtuális kiállítások, szemléletes tananyagok létrehozását...

A Hullámfürdő vagy más régi képgyűjtemény feltárásának alapproblémája, hogy az identitásokat egy-egy portré, vagy egészalakos fénykép alapján kellene beazonosítani. Ez volna a kezdőlépés a szöveges adatok felé. Bár a szöveg, a név sem egyértelmü azonosító (gondoljunk a névrokonokra, sőt névváltozatokra), egy írott nevet még a ragok, toldalékok és rövidítések dacára is nagy hatékonysággal és villámgyorsan ki lehet kerestetni - akár könyvtárnyi dokumentumból is. A fényképeken megörökített arcok beazonosítása azonban nehéz feladat. Az internetre, vagy egy közösségi hálóra feltöltött fényképek, sőt önarcképek tömegében az arcfelismerő algoritmusok jelentős mintán dolgozhatnak, egy-egy arcot több tucat fényképe alapján beazonosíthatnak az eltérések, frizuraváltozás, grimasz, fényviszonyváltozás ellenére is. Ugyanígy, a mobiltelefonokat vagy zárakat feloldó arcképes azonosítás is megbirkózhat kisebbnagyobb eltérésekkel, a hibajavítás felkészíthető éjszakai és nappali kontrasztokra, borostára, rúzsra, 
müszempillára is. Pusztai Sándor fotóalanyai azonban nincsenek a Facebookon, a korszak képanyaga összehasonlíthatatlanul kisebb, mint napjainké, s digitalizáltsága, nyomdai megjelentsége is töredékes. Vannak persze kivételek: színészek, politikusok, írók: öket ismerték fel elsők között, hiszen róluk több különböző portré, sztárfotó készült.

A bőséges, egységesen feldolgozható minta hiányában bevethetetlen képfelismerést és a betanítás nélkül tehetetlen mesterséges intelligenciát nem pótolhatta más, mint a több (természetes) szem - többet lát elve: kutatókat, a korszakkal foglalkozó történészeket kértünk föl, hogy nézzék át velünk a fürdőzőkröl, napozókról készült félezer fényképet, hátha felfednek még pár tucat ismerhető személyt. Bár a közös munka jó hangulatban zajlott, vendégeink többé-kevésbé csalódottan búcsúztak: hiába voltak szépek és jók a képek, nagyon nehéz volt bővíteni a beazonosított személyek körét.

- Nyolcvan év alatt belénk égnek az ismertté vált portrék beállításai, a felvételkor viselt ruha, frizura, az arckifejezés, a fej vállakkal, testtel bezárt szöge, a fejtartás; meghatározó a kamera nézőpontja, a világítás, még a háttér mélysége is.

- Nemcsak szokatlansága miatt kivételes élmény egyszerre, egy helyszínről félezer fényképes mintát kapni a fotózás hőskorának számító időszakból, de azért is izgalmas, mert a nagy mintát vizsgálva kiderülhet, hogy egy ismert személyhez kötött jellegzetes frizura, pajeszviselet vagy bajusz korántsem volt egyedi.

- Afényképek készítési dátumai bizonytalanok: a harmincas évek bármely szakaszában készülhettek. Tíz év sokat jelenthet, ha az ismert személyröl közismert kép a korszak elején rögzült, a Gellértben viszont az évtized végén örökítette meg a fürdőmester kamerája.

- Színészek, politikusok ismert ábrázolásai beállított vagy protokolláris eseményeken születtek. A frizurák, öltözékek, ékszerek, fejfedök teljes harci dísze s gyakran a retusálás is egészen más arcukat mutatja, mint amit Pusztai Sándor fényképén látunk: vakító napfényben, netán vizes hajjal, fürdődresszben, sok esetben a gyepről vagy medence partjáról felnézve a mellettük megálló fotográfusra.

Nincs más hátra, a „természetes” intelligenciához és képfelismeréshez erősebb „motort” kellett bevetnünk. A beazonosításokhoz szükséges minta létezhet, statisztikailag bizonyos, hogy megtalálható: családok féltve örzött fotóalbumaiban vagy csak pár, a falon bekeretezve évtizedekig látott fényképen, amely - az élet terének részeként - végigkísérte egy-egy olvasónk, látogatónk gyerekkorát a nagyszülők, szülők otthonában. Ahogy az összevethető mintákat egységes rendszerbe kapcsoló adatbázislekérdezések, úgy fordultunk mi, a projekt szervezői a látogatók személyes emléktára felé. Igyekeztünk létrehozni a lekérdező „platformot”, a gyüjteményt adekvát módon közreadva. Bízunk abban, hogy örömmel keresnek benne ismeröst, rokont, s kutatnak velünk Pusztai Sándor élményei között, hogy megtalálják a saját emlékeikben őrzött, s valamilyen szinten ismert élet - eddig sosem látott - Pusztai Sándor által megörökített mozzanatát. 


\section{NETWORKSHOP 2018}

\section{4. Összegzés}

A technológiai fejlődés egyre kifinomultabb, adatbázisokon átívelő rendszerekbe füzi digitalizált kulturális és tudományos örökségünket. Nem kérdés, hogy a hagyományos könyvtáros, levéltáros munkafolyamatok jelentős része kiváltható lesz algoritmusokkal. A Hullámfürdő projekt megvalósítása, a hallgatókkal végzett munka és a feltételezett olvasói aktivitás motiválására tett lépések azt bizonyítják, hogy a felhasználók és a gyűjtemények sokfélesége, a változatos szaktudást és háttérműveltséget igénylő kapcsolatok mégis, a jövőben is nélkülözhetetlenné teszik a közvetítő munkatárs alkotó, kreatív szerepvállalását.

Ez a közvetítő szerep már ma is jól látható, érzékelhető a közösségi médiában aktív gyüjtemények stratégiájában. A digitalizált gyüjtemények tervezésében, hosszú távú fenntartásában, a digitális újrahasznosításban esszenciális kompetencia a bevont könyvtáros szakemberek tudása, kreativitása. S nélkülözhetetlen, csak a könyvtártudományból származtatható rugalmasság biztosíthatja a digitális bölcsészek kreatívmegközelítéseinekátvételét, gyakorlatifelhasználásátajövőtájékoztatásifeladataiban. Ajövő gyűjteményeinek felhasználására már ma működő, eleven példát kell mutatniuk a könyvtárosoknak, mert ilyen példák sorával biztosíthatják hagyományos, közvetítő szerepük fennmaradását is.

A most elkészült projekt eredményét a következő évek során vizsgálhatjuk, elemezve az interakaciót a felkínált felületeken. A létrehozott Facebook-oldalon folytatjuk a gyűjteménnyel kapcsolatos ízelítők, frissítések közreadását, az eredményekröl 2019-ben adunk összegzést.

\section{Bibliográfia}

Fodor János, and Kiszl Péter. „Developing Digital Collections: a Training Model of Digital Humanities Web Projects in Library and Information Science Education." Informatio et Scientia. Information Science Research 1 (1) (2018): 1-27. https://wow.umcs.pl/czasopisma/controller/Default/module/Ejournals/action/ downloadContent/cid/81

Fodor János. „A megosztó hivatás. Könyvtári jelenlét a Facebook közösségi oldalon 2013/2014-ben”. Tudományos és Müszaki Tájékoztatás, 61. évf. 7-8. sz. (2014): 275-294.

Fodor János. „Megosztás vagy szerkesztés? A könyvtár változó szerepe a közösségi médiában.” Tudományos és Müszaki Tájékoztatás, 64. évf. 1 sz. (2017): 24-36.

Garner, Anne, Johanna Goldberg, and Rebecca Pou. „Collaborative Social Media Campaigns and Special Collections: A Case Study on \#ColorOurCollections." RBM: a Journal of Rare Books, Manuscripts, and Cultural Heritage 17 (2) (2016): 100-17. https://doi.org/10.5860/rbm.17.2.9663

Skulan, Naomi. „Staffing with students: Digitizing campus newspapers with student volunteers at the University of Minnesota, Morris." Digital Library Perspectives, 34. 1. (2018): 32-44. https://doi.org/10.1108/dlp-07-2017-0024 